\title{
HOT PEPPER (Capsicum chinense, Jacq.) INHERITANCE OF REACTION TO POWDERY MILDEW
}

\author{
Sally Ferreira Blat ${ }^{1}$; Cyro Paulino da Costa ${ }^{2 *}$; Roland Vencovsky ${ }^{3}$; Fernando Cesar Sala ${ }^{2}$ \\ ${ }^{1}$ APTA Regional/ Polo Centro Leste, C.P. 271 - 14001-970 - Ribeirão Preto, SP - Brasil. \\ ${ }^{2}$ USP/ESALQ - Depto. de Produção Vegetal, C.P. 09 - 13418-900 - Piracicaba, SP - Brasil. \\ ${ }^{3}$ USP/ESALQ - Depto. de Genética, C.P. 38 - 13418-900 - Piracicaba, SP - Brasil. \\ *Corresponding author <cpcosta@terra.com.br>
}

\begin{abstract}
The pepper species $C$. chinense has been considered one of the most important resistance sources to powdery mildew Capsicum spp. However, the inheritance in this species was unknown. The purpose of this work was to study its reaction inheritance. Two powdery mildew resistant parents, 'Pimenta Cheiro' 1 and PI 152225 and two moderately susceptible ones, 'Pimenta Doce' IH-1761 and 'Pimenta Índio', were used to obtain three $\mathrm{F}_{1}$ and their respective $\mathrm{F}_{2}$ generations: 'Pimenta Doce' IH-1761 × 'Pimenta Cheiro' 1, 'Pimenta Índio' X PI 152225 and 'Pimenta Doce' IH-1761 × PI 152225. The powdery mildew epidemy was natural using inoculum from a highly-sporulating susceptible pepper host. Powdery mildew host reaction evaluations were carried out during the fruiting stage using a rating system based on disease severity scales varying from 1 (resistant) to 5 (highly susceptible). The experimental design was completely randomized. The following genetic parameters were estimated: gene action, heritability coefficient and expected selection gain in the $\mathrm{F}_{3}$ generation. The transgressive segregation in $\mathrm{F}_{2}$ indicated oligogenic inheritance. Results show the presence of additive, dominant, and epistatic gene action. The dominant and epistatic effects detected in crosses presented negative values, tending towards susceptibility. The heritability and selection gain estimates were moderate, with values of $35.5 \%$ and $1.7 \%$ for 'Pimenta Doce' IH $1761 \times$ 'Pimenta Cheiro' 1 , from 50.4\% to 3.5\% for 'Pimenta Índio' $\times$ PI 152225 , and $49 \%$ and $2.7 \%$ for the 'Pimenta Doce' IH $1761 \times$ PI 152225 crosses, respectively. These gene action results are favorable for breeding programs and exploration of hybrids.

Key words: Leveillula taurica (LEV.) Arn., Capsicum chinense, genetic resistance, gene action
\end{abstract}

\section{HERANÇA DA REAÇÃO AO OÍDIO EM PIMENTA (Capsicum chinense, Jacq.)}

\begin{abstract}
RESUMO: A espécie de pimenta $C$. chinense tem sido considerada uma das mais importantes fontes de resistência ao oídio, porém a herança dessa resistência ainda é desconhecida. O objetivo deste trabalho foi obter informações sobre a herança dessa reação. Dois progenitores resistentes, Pimenta Cheiro 1 e PI 152225 e dois moderadamente suscetíveis, Pimenta Doce IH-1761 e Pimenta Índio, foram utilizados na obtenção de três híbridos e respectivas gerações $\mathrm{F}_{2}$ : Pimenta Doce $\mathrm{IH}-1761 \times$ Pimenta Cheiro 1, Pimenta Índio $\times$ PI 152225 e Pimenta Doce IH-1761 × PI 152225. A epidemia de oídio ocorreu de maneira natural a partir de inóculo mantido em plantas de pimentão suscetíveis. As avaliações das reações ao oídio foram feitas na fase de frutificação, através de uma escala de notas de 1 (resistente) a 5 (altamente suscetível). O delineamento experimental utilizado foi inteiramente casualizado. Foram estimados: tipo de ação gênica, coeficiente de herdabilidade e ganho de seleção esperado em $F_{3}$. A segregação transgressiva em $F_{2}$ indicou que a herança é oligogênica e o tipo de ação gênica envolveu os componentes aditivos, dominantes e epistáticos. Os efeitos de dominância e epistasia detectadas nos cruzamentos se mostraram negativos para a suscetibilidade. Os valores de herdabilidade e ganho de seleção foram moderados, sendo de $35,5 \%$ e $1,7 \%$ para o cruzamento Pimenta Doce IH- $1761 \times$ Pimenta Cheiro 1 , de $50,4 \%$ e 3,5\% para Pimenta Índio $\times$ PI 152225 e de 49,0\% e 2,7\% para Pimenta Doce IH $1761 \times$ PI 152225 . Os resultados sobre ação gênica favorecem programas de melhoramento visando variedades híbridas.

Palavras-chave: Leveillula taurica (LEV.) Arn., Capsicum chinense, resistência genética, ação gênica
\end{abstract}

\section{INTRODUCTION}

Brazil is an important biodiversity center of domesticated hot pepper of the Capsicum genus. The vari- ability of $C$. chinense is quite large, especially in the Amazon Valley and Northeastern part of Brazil (Bertão, 1993). Among pepper diseases, powdery mildew caused by Leveillula taurica is a quite serious world- 
wide pathogen of greenhouse crops. In Brazil it is an endemic disease especially under greenhouse conditions. Losses due to powdery mildew in sweet pepper can reach 75\% (Daubeze et al., 1995). This disease is considered to be difficult to control. Systemic fungicides with specificity to powdery mildew have not been effective. Crop management methods like sprinkle irrigation, crop rotation, bicarbonate and monopotassium phosphate could minimize powdery mildew damage. The best control practice would be by resistant varieties. Heredity studies of $C$. annuиm showed that resistance to powdery mildew is controlled by three genes with additive as well as epistatic effects (Shifriss et al., 1992, Daubeze et al., 1995, Blat et al., 2005b). Murthy \& Deshpande (1997) found resistance to be dominant and polygenic. Lima (2002) found higher occurrence of C. baccatum, C. chinense, and $C$. frutescens accessions resistant to powdery mildew while in $C$. annuum no typically susceptible accession was found. Most of $C$. chinense reaction to powdery mildew was highly resistant, like 'Pimenta Peixe-de-boi', or resistant like 'Pimenta Olho de Ganso', 'Pimenta de Cheiro', 'Pimenta do Maranhão', and 'Pimenta Picante'. The only moderately resistant accessions found were 'Pimenta' and 'Pimenta de Cheiro'.

According to Blat et al. (2005a), Lima (2002), and Souza \& Café-Filho (2003) the best resistance sources were found in the species $C$. chinense and no susceptible accessions were found. Therefore, inheritance in this species and its resistance reaction mechanism and expression are unknown. This paper tries to elucidate the resistance reaction of $C$. chinense to powdery mildew.

\section{MATERIAL AND METHODS}

Two powdery mildew-resistant parents, 'Pimenta Cheiro' 1 and PI 152225, and two moderately susceptible ones, 'Pimenta Doce' IH-1761 and 'Pimenta Índio', were used to obtain three hybrids and their respective $\mathrm{F}_{2}$ generations: 'Pimenta Doce' IH-1761 $\times$ 'Pimenta Cheiro', 'Pimenta Índio' $\times$ PI 152225, and 'Pimenta Doce' IH-1761 × PI 152225 . These hybrids were meant for the study on the genetic basis of resistance. The 'Pimenta Índio' $\times$ PI 152225 hybrid was autopollinated and also backcrossed to its PI 152225 resistant parent to increase gene resistance and to elucidate the powdery mildew resistance reaction.

The experiment was carried out using a plastic high tunnel in Piracicaba, SP, Brazil $\left(22^{\circ} 42^{\prime} 30^{\prime \prime} \mathrm{S}\right.$ $47^{\circ} 38^{\prime} 00^{\prime \prime} \mathrm{W}$, at an elevation of 546 meters). The powdery mildew epidemy occurred naturally. The initial in- oculation was obtained and maintained via susceptible sweet pepper plants with a high degree of sporulation. Plants that disseminated the pathogen were intercalated at a ratio of one susceptible plant to each fifteen tested accessions.

Seedlings were transplanted into eight-liter pots containing a plant substrate from Multiplanta ${ }^{\circledR}$ consisting of: Pinus bark, vermiculite, peat, macro and micro fertilizers, and Humix, plus 5\% sand. The experimental design was completely randomized with five plants per pot and 13 treatments, as follows: three hybrids, three $\mathrm{F}_{2}$ populations, four parents, one backcross, and two susceptible checks, totaling 2,098 plants.

Powdery mildew reaction evaluations were made at fruit development, 116 days after seeding. A rating scale was used according to affected leaf area, proposed by Ullasa et al. (1981), where: 1 - resistant, no symptoms, 2 - moderately resistant, with $10 \%$ of the leaf area affected; 3 - moderately susceptible, with $11-20 \%$ of the leaf area affected; 4 susceptible, with $21-50 \%$ of the leaf area affected and 5 - highly susceptible, with $51 \%$ or more of the leaf area affected. Hybrids 'Margarita' and 'Magali' $\mathrm{R}$ were used as susceptible checks, while variety HV12 and line PI 152225 were used as resistant checks. Populations were evaluated when reference check plants achieved a maximum score of 5 .

The following estimates were obtained: (a) type of gene action, using the additive-dominant and epistatic model in accordance to Mather \& Jinks (1981), with significance verified by the $t$ test according to Gomes (1990); (b) broad sense heritability coefficient $\left(\mathrm{h}^{2}\right)$, and (c) selection gain (Gs) expected in $F_{3}$ according to Vencovsky \& Barriga (1992). The broad sense heritability coefficient was employed to predict the expected gain from selection (Gs) in $F_{3}$, and was adequate in cases of absence of dominance. With any evidence of dominance, the Gs value is overestimated, serving only as a reference.

\section{RESULTS AND DISCUSSION}

As mentioned, $C$. chinense is considered a resistance good source and Blat et al. (2005a) found that $85 \%$ of all examined accessions a collection were highly resistant, without typical susceptible plants like in $C$. annuum. Few accessions were identified as moderately susceptible, such as 'Pimenta Doce' IH1761 and 'Pimenta Índio'. These presented scores between 2 and 3, with average values of 2.56 and 2.63 , respectively (Tables 1 and 2) and had different reactions in comparison with those identified in $C$. 
annuum. In others words, the susceptibility reaction of C. annuum is much more severe to powdery mildew than that of the $C$. chinense genetic background (Blat et al., 2005a).

An interesting reaction expression of $C$. chinense was defoliation, observed even in resistant accessions. Lima (2002) also observed this phenomenon in C. chinense, C. baccatum, and C. frutescens. This author explained the defoliation reaction expression as being due to a phenological characteristic and to temperature and humidity variations. This defoliation reaction of a resistant in accesses $C$. chinense can be explained as a host hypersensitivity due to high pathogen pressure (Carver et al., 1995). Under low powdery mildew pressure, the source of $C$. chinense resistance shows more intense leaf retention.

The $F_{1}$ generation means from the cross between resistant and susceptible parents ranged from 1 to 2 , indicating resistance. These $F_{1}$ means were specifically as follows: 1.74 for the 'Pimenta Doce' IH $1761 \times$ 'Pimenta Cheiro' 1 hybrid; 1.73 for 'Pimenta Indio' $\times$ PI 152225, and 1.18 for 'Pimenta Doce' IH $1761 \times$ PI 152225, which was the lowest mean. For the corresponding $\mathrm{F}_{2}$ generations, the reactions means of disease severity were also low, at 1.47, 1.56, and 1.43 , respectively. In these segregating generations plants with scores of 3 and 4 were quite rare, occurring with frequencies of $4.0 \%, 6.6 \%$, and $4.8 \%$, re- spectively. No plants with a score of 5 were found. Heterosis estimates indicated that the inheritance of the reaction to powdery mildew is dominant towards resistance. Dominance epistatic effects were detected in all crosses, acting to increase resistance, in comparison with the expected under an additive-dominant model. These results are favorable for programs for hybrid variety exploration.

Significant epistatic effects were found in the ('Pimenta Indio' $\times$ PI 152225$) \times$ PI 152225 backcross, confirming the $F_{2}$ results. In fact, the $F_{2}$ mean found was 1.56 , while the backcross mean was 1.32 , with a $2.9 \%$ increase in plants with scores 1 and 2 (Tables 1 and 2).

Transgressive segregants observed in the F2 populations can be considered an evidence that the reaction of $C$. chinese to powdery mildew is of an oligogenic nature. In fact, plants with scores of up to 4 were found within all three segregating generations; this value is beyond the parental scores of 1 (resistant) and 3 (susceptible) (Table 1).

Estimates for broad sense heritability and expected gain from selection were moderate, $35.5 \%$ and $1.7 \%$ for the segregating generation of 'Pimenta Doce' IH $1761 \times$ 'Pimenta Cheiro' I, 50.4\% and 3.5\% for 'Pimenta Indio' $\times$ PI 152225 , and $49.0 \%$ and $2.7 \%$ for 'Pimenta Doce' IH $1761 \times$ PI 152225 , respectively (Table 2).

Table 1 - Number of segregating plants of Capsicum chinense for reaction to Leveillula taurica under greenhouse conditions, using a disease severity rating scale, Piracicaba, 2003.

\begin{tabular}{|c|c|c|c|c|c|c|}
\hline \multirow{2}{*}{ Generation } & & \multirow{2}{*}{$\begin{array}{c}\mathrm{R} \\
\text { Score } 1\end{array}$} & \multirow{2}{*}{$\begin{array}{c}\text { MR } \\
\text { Score } 2\end{array}$} & \multirow{2}{*}{$\begin{array}{c}\text { MS } \\
\text { Score } 3\end{array}$} & \multirow{2}{*}{$\begin{array}{c}\mathrm{S} \\
\text { Score } 4\end{array}$} & \multirow{2}{*}{$\begin{array}{c}\text { AS } \\
\text { Score } 5\end{array}$} \\
\hline & & & & & & \\
\hline 'Pimenta Cheiro' 1 & PR & 30 & 25 & 0 & 0 & 0 \\
\hline PI 152225 & PR & 38 & 12 & 0 & 0 & 0 \\
\hline 'Pimenta Doce' IH-1761 & PMS & 0 & 24 & 31 & 0 & 0 \\
\hline 'Pimenta Índio' & PMS & 0 & 22 & 38 & 0 & 0 \\
\hline HV-12 & TR & 40 & 0 & 0 & 0 & 0 \\
\hline 'Magali' R & TS & 0 & 0 & 0 & 0 & 40 \\
\hline 'Margarita' & TS & 0 & 0 & 0 & 0 & 40 \\
\hline \multirow[t]{2}{*}{ 'Pimenta Doce' IH-1761 × 'Pimenta Cheiro' 1} & $\mathrm{~F}_{1}$ & 13 & 37 & 0 & 0 & 0 \\
\hline & $\mathrm{F}_{2}$ & 298 & 203 & 19 & 2 & 0 \\
\hline \multirow[t]{3}{*}{ 'Pimenta Índio' × PI 152225} & $\mathrm{~F}_{1}$ & 15 & 40 & 0 & 0 & 0 \\
\hline & $\mathrm{F}_{2}$ & 277 & 227 & 31 & 5 & 0 \\
\hline & $\mathrm{RC}$ & 76 & 26 & 4 & 0 & 0 \\
\hline \multirow[t]{2}{*}{ 'Pimenta Doce' IH-1761 × PI 152225} & $\mathrm{~F}_{1}$ & 45 & 10 & 0 & 0 & 0 \\
\hline & $\mathrm{F}_{2}$ & 291 & 156 & 21 & 2 & 0 \\
\hline
\end{tabular}

PR - resistant parent, PMS - moderately susceptible parent, TS - susceptible checks, TR - resistant check, RC - resistant parental backcross. R - resistant, MR - moderately resistant, MS - moderately susceptible, S - susceptible, AS - highly susceptible. 
Table 2 - Number of plants (n) and mean disease severity scale estimates, respective variances, heritability $\left(\mathrm{h}^{2}\right)$, heterosis $(\mathrm{H}$ nd $\mathrm{H} \%$ ), and epistasis (C) with significance by the $\mathrm{t}$ test and expected selection gain in $\mathrm{F}_{3}(\mathrm{Gs})$ for Capscium chinense, Piracicaba 2003.

\begin{tabular}{|c|c|c|c|c|c|c|c|c|c|}
\hline \multirow[t]{2}{*}{ Generation } & & $\mathrm{n}$ & Means & Variances & $\mathrm{H}^{\mathrm{a}, \mathrm{b}}$ & $\mathrm{Gs}^{\mathrm{b}}$ & $\mathrm{H}^{\mathrm{a}}$ & $\mathrm{H}^{\mathrm{a}}$ & $\mathrm{C}^{\mathrm{a}}$ \\
\hline & & & & & \multicolumn{5}{|c|}{ - } \\
\hline 'Pimenta Cheiro' 1 & PR & 55 & 1.45 & 0.252 & & & & & \\
\hline PI 152225 & PR & 50 & 1.24 & 0.186 & & & & & \\
\hline 'Pimenta Doce' IH-1761 & PMS & 55 & 2.56 & 0.250 & & & & & \\
\hline 'Pimenta Índio' & PMS & 60 & 2.63 & 0.236 & & & & & \\
\hline HV-12 & TR & 40 & 1.00 & 0.000 & & & & & \\
\hline Magali R & $\mathrm{TS}$ & 40 & 5.00 & 0.000 & & & & & \\
\hline Margarita & TS & 40 & 5.00 & 0.000 & & & & & \\
\hline \multirow[t]{2}{*}{ 'Pimenta Doce' IH-1761 × 'Pimenta Cheiro' 1} & $\mathrm{~F}_{1}$ & 50 & 1.74 & 0.196 & & & $-0.26 * * *$ & -13.0 & \\
\hline & $\mathrm{F}_{2}$ & 522 & 1.47 & 0.346 & 35.5 & $-1.70^{\wedge}$ & & & $-0.40 * * *$ \\
\hline \multirow[t]{3}{*}{ 'Pimenta Índio' × PI 152225} & $\mathrm{~F}_{1}$ & 55 & 1.73 & 0.202 & & & $-0.20 * * *$ & -10.4 & \\
\hline & $\mathrm{F}_{2}$ & 540 & 1.56 & 0.417 & 50.4 & $-3.53^{\wedge}$ & & & $-0.27 * * *$ \\
\hline & $\mathrm{RC}$ & 106 & 1.32 & 0.296 & & & & & \\
\hline \multirow[t]{2}{*}{ 'Pimenta Doce' IH-1761 × PI 152225} & $\mathrm{~F}_{1}$ & 55 & 1.18 & 0.151 & & & $-0.72 * * *$ & -37.9 & \\
\hline & $\mathrm{F}_{2}$ & 470 & 1.43 & 0.361 & 49.0 & $-2.73^{\wedge}$ & & & $-0.11 * * *$ \\
\hline
\end{tabular}

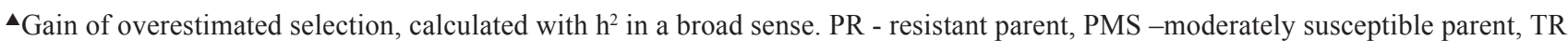
- resistant checks; TS - susceptible checks, RC - Resistant parental backcross. ${ }^{\mathrm{a} I n}$ accordance with Mather and Jinks, (1981). ${ }^{\mathrm{b}} \mathrm{In}$ accordance with Vencovsky and Barriga (1992). ***Significance based on the $t$ test at $0.1 \%$ probability

\section{ACKNOWLEDGMENTS}

To FAPESP for the scholarship of the first author.

\section{REFERENCES}

BERTÃO, M.R. Evolução cariotípica no gênero Capsicum (Solanaceae). Piracicaba: USP/ESALQ, 1993. 148p. (Dissertação - Mestrado).

BLAT, S.F.; COSTA, C.P.; VENCOVSKY, R.; SALA, F.C. Reação de acessos de pimentão e pimentas ao oídio (Oidiopsis taurica). Horticultura Brasileira, v.23, p.72-75, 2005a.

BLAT, S.F.; COSTA, C.P.; VENCOVSKY, R.; SALA, F.C. Inheritance of reaction to Leveillula taurica (Lev.) Arn. in Capsicum annuиm L. Scientia Agricola, v.62, p.40-44, 2005 b.

CARVER, T.L.W.; ZEYEN, R.J.; LYNGKJAER, M.F. Plant cell defences to powdery mildew of Graminae. Aspects of Applied Biology, v.42, p.257-266, 1995.

DAUBEZE, A.M.; HENNART, J.W.; PALLOIX, A. Resistance to Leveillula taurica in pepper (Capsicum annuum) is ologogenically controled and stable in Mediterranean regions. (Compact disc). Plant Breeding, v.114, p.327-332, 1995.

GOMES, F.P. Curso de estatística experimental. Piracicaba: Editora Nobel, 1990. 467p.
LIMA, M.L.P Resistência genética e aspectos epidemiológicos, fisiológicos e anatômicos da infecção de Oidiopsis taurica em Capsicum spp. Brasília: UnB/IB, 2002. 130p. (Dissertação Mestrado).

MATHER, K.; JINKS, J.L. Biometrical genetics. 3.ed. London: Butler \& Tanner, 1981. 382p.

MURTHY, H.M.K.; DESHPANDE. A.A. Studies on genetics of powdery mildew (Leveillula taurica (Lév.) Arn.) resistance in chilli (Capsicum annuиm L.). Vegetable Science, v.24, p.127131, 1997.

SHIFRISS, C.; PILOWSKY, M.; ZACKS, J.M. Resistance to Leveillula taurica mildew (=Oidiopsis taurica) in Capsicum annuиm. Phytoparasitica, v.20, p.279-283, 1992.

SOUZA, V.L.; CAFÉ-FILHO, A.C. Resistance to Leveillula taurica in genus Capsicum. Plant Pathology, v.52, p.613-619, 2003.

ULLASA, B.A.; RAWAL, R.D.; SOHI, H.S.; SINGH, D.P. Reaction of sweet pepper genotypes to Anthracnose, Cercospora leaf spot, and Powdery Mildew. Plant Disease, v.65, p.600-601, 1981.

VENCOVSKY, R.; BARRIGA, P. Genética biométrica no fitomelhoramento. Ribeirão Preto: Sociedade Brasileira de Genética, 1992. 496p.

Received November 29, 2005

Accepted July 19, 2006 